Japan, J. Med. Sci. Biol., 36, 85-95, 1983

\title{
A SERUM-DEPRIVED HUMAN EMBRYO PANCREATIC ISLET CELL CULTURE SYSTEM: A CULTURE METHOD SUITABLE FOR DOUBLE-LABEL ANTIBODY TECHNIQUE TO DETECT VIRUS INFECTION OF BETA CELLS
}

\author{
Shigehiro SATO, Masato MAKINO and Rinji KAWANA \\ Department of Bacteriology, Iwate Medical University, \\ Uchimaru, Morioka 020
}

(Received November 13, 1982. Accepted January 13, 1983)

\begin{abstract}
SUMMARY: By the use of serum-free Eagle's MEM instead of serum-supplemented culture medium in human embryo islet cell culture, it was possible to increase the proportion of beta cells identified by the indirect fluorescent antibody (IFA) technique.

With the combination of the serum-deprived culture system and the doublelabel antibody technique, it was possible to show that the human embryo beta cells in culture were susceptible to infection with human papovavirus BK (BKV). Furthermore, this combination enabled us to assay quantitatively the BKV-infected beta cells, and it was shown that the proportion of BKV-infected beta cells in the islet cultures from three subjects were not significantly different either in BKV tumor antigen ( $\mathrm{T}-\mathrm{Ag}$ )-positive ratio or in $\mathrm{BKV}$ virion antigen ( $\mathrm{V}-\mathrm{Ag})$-positive ratio.

The quantitative assay also showed that the percentages of BKV T-Ag- or V-Agpositive cells in insulin-positive cells and in insulin-negative cells were almost the same.
\end{abstract}

\section{INTRODUCTION}

It has already been reported that the double-label antibody technique is a useful method for detecting viral antigens in cultured human pancreatic beta cells (Prince et al., 1978; Yoon et al., 1978). By the use of this technique, pilot experiments have been made in our laboratory to study the susceptibility of cultured human embryo pancreatic beta cells to BKV. However, one difficulty arising in the embryo islet cell culture is the fact that very few beta cells are identified by the indirect fluorescent antibody (IFA) technique. We thought that the number of detectable beta cells could be increased if a better culture method was found. Thus we attempted to establish a human embryo islet culture system suited for studies by the double-label antibody technique. For this purpose, the effect of calf serum on the number of beta cells identifiable by the IFA technique has been studied, since in recent studies of the culture technique, attention has been paid to the important role of calf serum for the

佐藤成大・牧野正人・川名林治（岩手医科大学医学部細菌学教室 盛岡市内丸 19-1) 
attachment of the islets to culture dishes (Goldman and Colle, 1976) and for their hormone production (Andersson, 1978; Andersson and Hellerstrom, 1977) or replication (King, Chick and Kitchen, 1977).

We showed that in contrast to the islets cultured in Eagle's MEM supplemented with $2-10 \%$ calf serum, those maintained in the serum-free MEM displayed significantly decreased insulin release and markedly increased beta cells detectable by the IFA technique. Furthermore, BKV antigens were detected in the beta cells cultured in the serum-free medium. In the present paper, we would like to report the advantage of this serum-deprived human embryo islet cell culture system especially for the double-label antibody technique.

\section{Materials ANd Methods}

Islet cell culture: Primary human embryo pancreatic islet cell cultures were prepared by essentially the same method as described for rodent islet monolayer culture (Lambert et al., 1972).

We used the pancreas of human fetuses obtained through legal abortion from clinically healthy mothers in 20-26 weeks of gestation. Tissues were removed aseptically, cut into small pieces, and then incubated in a $0.25 \%$ trypsin solution containing $80 \mathrm{mg} / \mathrm{dl}$ collagenase (Worthington, type IV). Digestion was stopped by pelleting the dissociated cells by low centrifugation followed by washing them with culture medium. This step was repeated and the final pellet was resuspended in Eagle's MEM supplemented with $10 \%$ heat-inactivated calf serum. This primary cell suspension was settled for $18-22 \mathrm{hr}$ at $37 \mathrm{C}$ to eliminate a large number of fibroblastoid cells (Lambert et al., 1972), and then decanted into new culture vessels.

Immunoassay of culture medium for insulin: Immunoreactive insulin (IRI) was measured by the two-antibody system (Morgan and Lazarow, 1963) with aliquots of culture medium with commercially available I-131 insulin kit (Dinabot).

Electron microscopy: The islet cells were fixed for $30 \mathrm{~min}$ at $4 \mathrm{C}$ in a $2.0 \%$ glutaraldehyde solution, and then scraped off with a rubber policeman. The cells were post-fixed in cold $1 \%$ phosphate-buffered osmium tetroxide, then dehydrated in ethanol solutions and embedded in epoxy resin (Epon 812). Thin sections were prepared in the usual manner and examined under a JEM-100B electron microscope.

IFA technique: (I) Antisera. (i) Anti-insulin serum was prepared by inoculating guinea pigs intramuscularly with crystallized beef insulin (Novo) with Freund's complete adjuvant (Ogata, 1970). The specificity of antiserum was demonstrated by allowing it to react it with Bouin-fixed human embryo beta cells in a paraffin section (Fig. 1). Absorption of the anti-insulin serum with purified pork insulin (Novo; monocomponent pork insulin) blocked the staining (data not shown).

(ii) Anti-BKV V serum was made in rabbits by inoculating BKV (Gardner 
strain) purified by sedimentation onto a cushion of a $\mathrm{KBr}$ solution followed by $\mathrm{CsCl}$ equilibrium density centrifugation (Uchida et al., 1976).

(iii) Anti-BKV $\mathrm{T}$ serum was obtained from hamsters bearing a BKVinduced osteosarcoma (Uchida et al., 1979).

Each of these antisera was found to have a specific staining activity to the homologous antigen when tested with human embryo kidney cells infected with BKV.

(iv) FITC-labeled anti-guinea-pig IgG was purchased from Miles Lab. The IgG fraction of anti-rabbit IgG serum and that of anti-hamster IgG serum were labeled with tetramethyl rhodamine isothiocyanate (TRITC; BBL) (Kawamura, 1977).

(II) Detection of beta cells. The monolayers were fixed with a $2.5 \%$ paraformaldehyde solution (Wicker and Avrameas, 1979) for $40 \mathrm{~min}$ at room temperature. The preparations were stained by the IFA technique with antiinsulin serum at room temperature.

(III) Double-label antibody technique. (i) Inoculation of viruses: To detect viral antigens in the nucleus of beta cells, we used BKV because of the following reasons: (a) The intranuclear antigens are easily distinguishable from the insulin antigen in the cytoplasm. (b) Intracutaneous or iv inoculation of $\mathrm{BKV}$ into hamsters results in high incidence of $\mathrm{BKV}$-induced insulinomas (Corallini et al., 1978; Uchida et al., 1976, 1979).

Islet cultures were infected with BKV $\left[4.4 \times 10^{4} \mathrm{~V}\right.$-Ag-forming units (Aaronson and Todaro, 1970)] on the third or fourth culture day.

(ii) Staining procedure (Prince et al., 1978): (a) The islet cultures were fixed with a $2.5 \%$ paraformaldehyde solution for $20 \mathrm{~min}$ for $\mathrm{BKV} \mathrm{T}-\mathrm{Ag}$ and $40 \mathrm{~min} \mathrm{BKV}$ at $4 \mathrm{C}$. (b) They were left overnight at $4 \mathrm{C}$ in $0.05 \mathrm{M}$ phosphate buffer ( $\mathrm{pH} 7.2$ ) containing $7.5 \%$ sucrose, then washed, and dried at room temperature. (c) Anti-insulin serum was added to the cells and the antiserum corresponding to the viral antigen. The mixture was incubated for $60 \mathrm{~min}$ at room temperature. (d) After washing and drying, they were incubated by the same step as in (c) with TRITC-labeled secondary antibody. (e) They were washed, dried, and incubated again as in step (c) with FITC-labeled secondary antibody. (f) After washing and mounting, they were examined under a Nikon fluorescent microscope (FL type).

\section{Results}

\section{Islet Cell Culture}

(i) Light microscopy. Most of the islets cultured in the medium supplemented with $10 \%$ calf serum attached to the glass coverslips within initial $24 \mathrm{hr}$ and started to form a monolayer (Fig. 2). The islets maintained in the medium with $2 \%$ calf serum continued to fan out, but those maintained in serum-free MEM stopped spreading. Once formed, however, the monolayers were well preserved in the serum-deprived system for 2-3 weeks. 


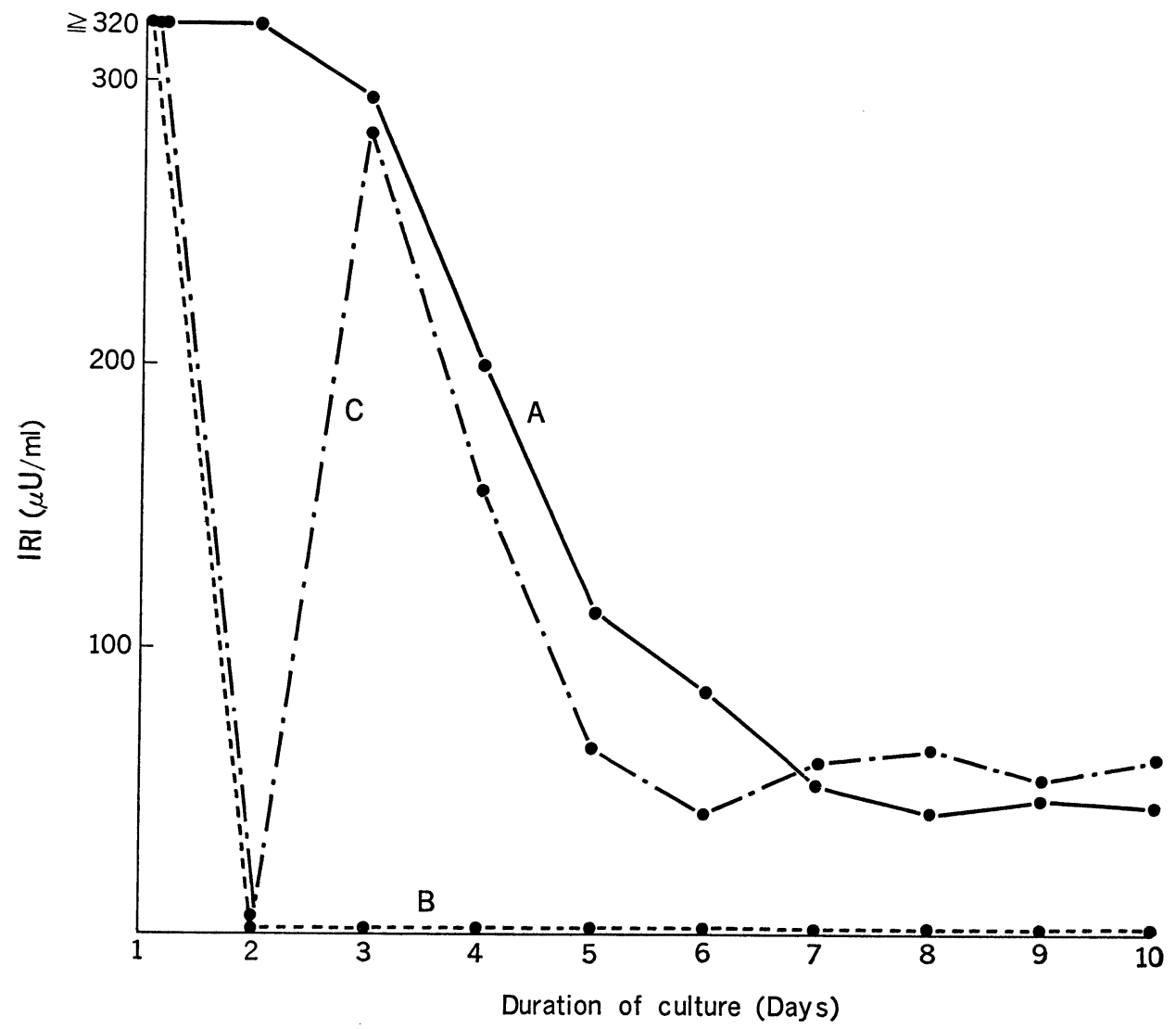

Fig. 3. IRI concentration in the culture medium. The islet cells were cultured in medium consisting of either (A) $98 \%$ Eagle's MEM and $2 \%$ calf serum, (B) MEM alone, or (C) MEM alone for $24 \mathrm{hr}$, followed by $98 \%$ MEM and $2 \%$ calf serum. Half of the culture medium was collected daily for IRI assay.

(ii) IRI assay. After 2-3 days of culture, the medium was replaced by a fresh medium consisting of (a) 98\% Eagle's MEM and 2\% calf serum, (b) MEM alone, or (c) MEM alone for $24 \mathrm{hr}$ followed by $98 \% \mathrm{MEM}$ and $2 \%$ calf serum. Half of the culture medium was collected daily for IRI assay after the initial plating. As shown in Fig. 3, the insulin release by the islets shifted from MEM containing $10 \%$ calf serum to MEM alone was markedly reduced in contrast to that by those cultured in MEM containing $2 \%$ calf serum, and it was found also that the insulin release increased when the islets were shifted from MEM alone to that containing $2 \%$ calf serum. From these data, we conclude that calf serum was required to increase insulin release. The responsiveness of the islet to calf serum was unchanged for 21 days in culture (data not shown).

(iii) Detection of beta cells by the IFA technique. The insulin stained 
TABLE I

Increased percentage of insulin-positive cells in serum-free MEM

\begin{tabular}{ccc}
\hline $\begin{array}{c}\text { No. of } \\
\text { experiment }\end{array}$ & $\begin{array}{c}\text { Serum } \\
\text { concentration } \\
(\%)\end{array}$ & $\begin{array}{c}\text { Insulin-positive } \\
\text { cells/islet cells } \\
(\%)\end{array}$ \\
\hline 1 & 2 & 0 \\
2 & 2 & $<1^{*}$ \\
3 & 2 & $<1$ \\
4 & 2 & $<1$ \\
5 & 0 & 5 \\
6 & 0 & 3 \\
7 & 0 & 9 \\
8 & 0 & 4 \\
9 & 0 & 5 \\
\hline
\end{tabular}

Percentage of insulin positive cells/islet cells detected by the IFA technique on the 6th or 7th day of cultivation in human embryo pancreatic islet cell cultures maintained in MEM supplemented with 0 or $2 \%$ calf serum.

* There were several insulin-containing cells in the culture.

by the IFA technique showed homogeneous or granular distribution in the cytoplasm.

Few insulin-containing beta cells were identified into the islet cultures (in four experiments) maintained in MEM containing 2\% calf serum for 6-7 days after the initial plating (Table I). However, insulin was detected in 3-9\% (in five experiments) of the islet cells incubated in serum-free MEM after the same culture period (Table I).

(iv) Electron microscopy. Ultrastructurally, the beta cells incubated in serum-free MEM appeared well preserved even after 7 days of cultivation, and well granulated glucagon-containing cells or somatostatin-containing cells were also observed (Fig. 4a and b).

(v) Cytopathic effect of BKV on the islet cells. The islet cultures were monitored daily by phase contrast microscopy after inoculation of BKV. BKVinoculated monolayers showed no evidence of morphological alterations up to 5-6 days of inoculation except the appearance of intranuclear inclusion bodies.

\section{Double-label Antibody Technique}

(i) Detection of BKV antigens in beta cells. The cultures infected with $\mathrm{BKV}$ were stained either 4 days (for BKV T-Ag) or 6 days later (for BKV V-Ag) by the double-label antibody technique. Figure 5a shows a cell containing both BKV T-Ag in the nucleus and insulin in the cytoplasm. Figure 5b shows BKV V-Ag-containing beta cells.

(ii) Quantitative assay for the BKV-infected beta cells. To study in more detail the replication of $\mathrm{BKV}$ in islet cell cultures, the percentage of insulincontaining beta cells that had $\mathrm{T}-\mathrm{Ag}$ or $\mathrm{V}-\mathrm{Ag}$ in the islet cultures was calculated 


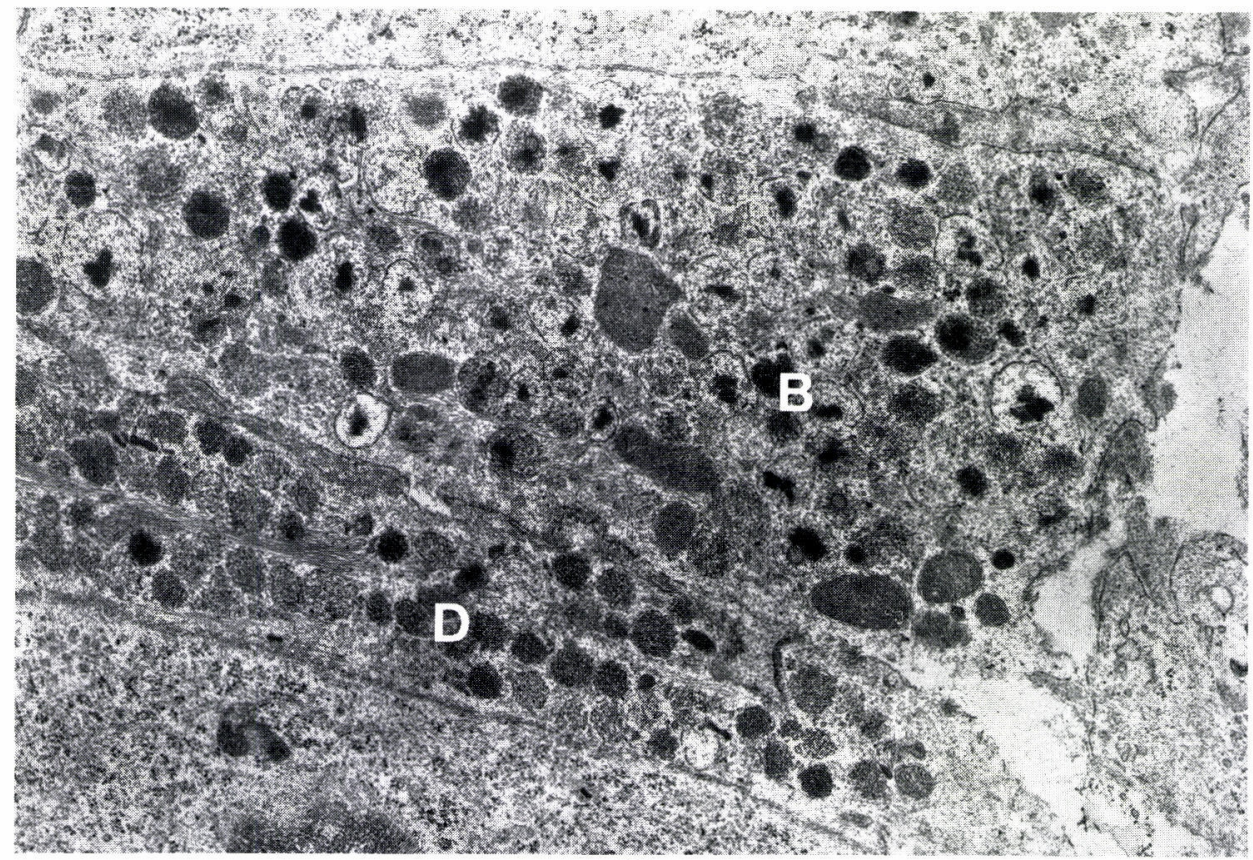

4 (a)

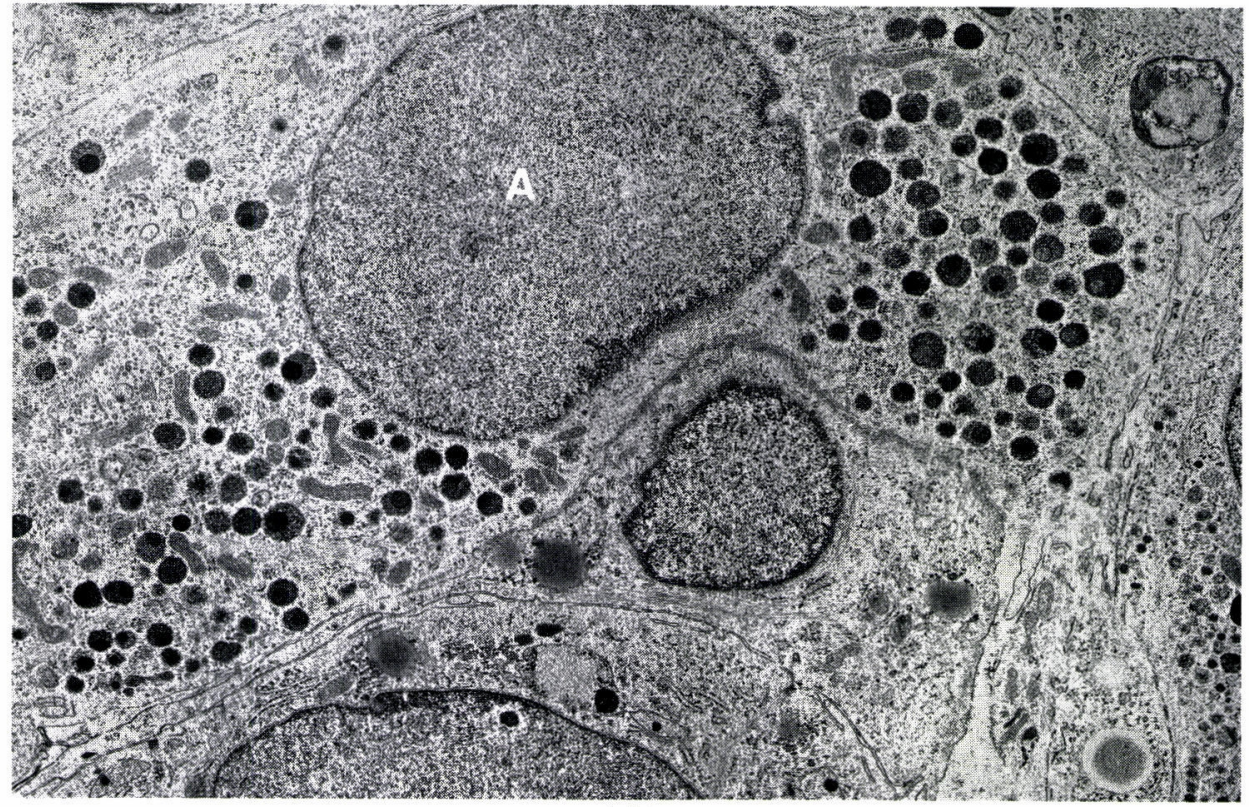

4 (b)

Fig. 4. Electron microscopy of cultured islet cells: Human embryo islet cells were incubated for 7 days in serum-free Eagle's MEM. (a) Beta cell (B), Delta cell (D). (b) Alpha cell (A). 
by the double-label antibody technique. For this purpose, the islet cultures from three subjects were examined. The data in Fig. 6 show that the percentage of BKV T-Ag-containing beta cells in the cultures from the same subject increased from $8.5 \%$ (the mean of two experiments) on the 2nd day of infection to $50 \%$ (the mean of three experiments) on the 4 th day. No BKV V-Ag-containing beta cell was detected on the 2 nd day of infection. The percentage of V-Agcontaining beta cells in the cultures then increased for the next 4 days. On day 6 after infection, $40 \%$ (the mean of three experiments) of the beta cells contained BKV V-Ag.

The percentages were almost the same in BKV T-Ag- and V-Ag-positive cells in both insulin-positive and negative cells (Table II).

\section{Discussion}

Immunoreactive insulin assay showed that the insulin release from the beta cells decreased markedly when they were shifted from MEM containing $10 \%$ calf serum to calf serum-free MEM. In addition, increasing the serum con-

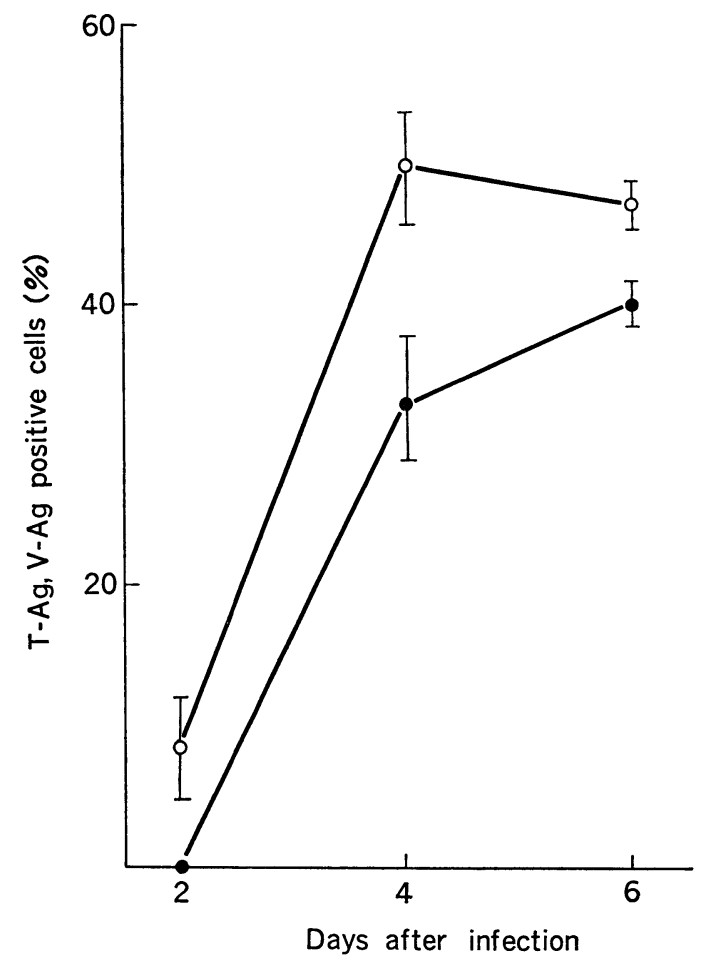

Fig. 6. Time course of the percentage of BKV T-Ag containing beta cells $(-\mathrm{O}-)$ V-Ag containing beta cells (- - ) in the islet cell cultures from the same subjects. Each point represents the mean of 2-3 cultures. 
TABLE II

Infectious rate of $B K V$ in insulin-positive cells or in insulin-negative cells

\begin{tabular}{cccccc}
\hline \multirow{2}{*}{$\begin{array}{c}\text { No. of } \\
\text { experiment }\end{array}$} & $\begin{array}{c}\text { T-Ag- or V-Ag-positive } \\
\text { cells/insulin-positive cells } \\
(\%)\end{array}$ & & \multicolumn{2}{c}{$\begin{array}{c}\text { T-Ag- or V-Ag-positive } \\
\text { cells/insulin-negative cells } \\
(\%)\end{array}$} \\
\cline { 2 - 3 } \cline { 5 - 6 } \cline { 5 - 6 } & T-Ag* & V-Ag** & & T-Ag & V-Ag \\
\hline 1 & 54 & & & 41 & \\
2 & 54 & & & 52 & 22 \\
3 & & 29 & & & 39 \\
4 & & 40 & & & \\
\hline
\end{tabular}

This table shows BKV-infected human embryo pancreatic islet cells in \%: Percentage of T-Ag-, or V-Ag-positive cells/insulin-positive cells. Percentage of T-Ag-, V-Ag-positive cells/insulin-negative cells.

* T-Ag was assayed on the 4th day of infection.

** V-Ag was assayed on the 6th day of infection.

centration in the medium from $0 \%$ to $2 \%$ resulted in a markedly increased insulin content in the culture fluid. The stimulatory effect of calf serum on the insulin release observed here is consistent with the earlier observations: (i) Andersson (1978) found that collagenase-isolated mouse islets maintained in the absence of calf serum had an impaired glucose-stimulated insulin biosynthesis. (ii) Collier et al. (1981) noted that the fetal pancreata grown in the medium supplemented with $5 \%$ fetal calf serum secreted less insulin than did the tissues grown in more than $10 \%$ fetal calf serum.

Although the insulin release from the beta cells was reduced significantly in the serum-deprived culture system, the islet cells were maintained in this system without difficulty once attached to the culture vessels (King et al., 1977). Furthermore, electron microscopic examinations showed that the beta cells and other endocrine cells were well granulated even in the serum-free medium. These results led us to the conclusion that in the absence of the stimulatory effect of calf serum on the insulin release, insulin granules were well retained in the cytoplasm. Therefore, by the use of such a serum-deprived human embryo islet cell culture system preserving insulin granules, it was possible to increase the number of beta cells identifiable by the IFA technique.

By the combination of the serum-deprived culture system and the doublelabel antibody technique, it was possible to show that the human embryo beta cells were susceptible to infection by BKV. However, BKV infection did not display a significant morphological alteration in light microscopy up to 5-6 days after inoculation.

By the quantitative assay for the BKV-infected beta cells in the serumdeprived culture system, the percentage of BKV V-Ag-containing beta cells increased until the 6th day of infection and the beta cells remained viable during this culture period.

The quantitative assay showed also that the proportion of BKV-infected 
beta cells in the islet cultures from three subjects was not significantly different either in $\mathrm{T}$-Ag-positive ratio nor in $\mathrm{V}$-Ag-positive ratio. The percentages were almost the same in BKV $\mathrm{T}$-Ag-and $\mathrm{V}$-Ag-positive cells in both insulin-positive and negative cells.

In preliminary experiments, however, it was observed that the islet cells obtained from subjects younger than 20 weeks were more sensitive to BKV infection than were the cells from the subjects examined here. However, the in vitro susceptibility of beta cells to $\mathrm{BKV}$ may not be a true reflection of the in vivo status of beta cells, although it was not the purpose of this study to examine beta cells for the in vivo susceptibility to a variety of viruses.

From the data obtained here, we conclude that the serum-deprived human embryo islet cell culture system may serve as an efficient tool for investigating the sensitivity of the isolated embryo beta cells to other viruses. Moreover, it seems that this culture system could be applicable to other pancreatic endocrine cells in studying their sensitivities to viruses.

\section{AcKNowledgement}

The authors gratefully acknowledge Prof. S. Uchida of the Department of Viral Infection, Institute of Medical Science, University of Tokyo, for his generously supplying BKV and BKVinduced osteosarcoma, to Prof. C. Ide for evaluating the electron micrographs, and to Prof. K. Yagawa and Prof. R. Satodate for their valuable advice.

\section{REFERENCES}

Aaronson, S. A. And Todaro, G. J. (1970): Infections SV40 and SV40 DNA: Rapid fluorescent focus assay. Proc. Soc. Exptl. Biol. Med., 134, 103-106.

Andersson, A. (1978): Isolated mouse pancreatic islets in culture: Effects of serum and different culture media on the insulin production of the islets. Diabetologia, 14, 397-404.

Andersson, A. ANd Hellerstrom, C. (1977): Isolated pancreatic islets in tissue culture: An investigative tool for studies of islet metabolism and hormone production. p. 55-63. In E. von Wasielewski, and W. L. Chick [eds.]. Pancreatic beta cell culture, Workshop Conferences Hoechst, Vol. 5, Excerpta Medica, Amsterdam-Oxford.

Collier, S., Mandel, T. E., Hoffman, L. and Caruso, G. (1981): Organ culture of fetal mouse pancreas: The effect of culture conditions on insulin and gulcagon secretion. Diabetes, 30 , 804-812.

Corallini, A., Altavila, G., Cecchetti, M. G., Fabris, G., Grossi, M. P., Balboni, P. G. and Barbanti-Brodano, G. (1978): Ependymomas, malignant tumors of pancreatic islets, and osteosarcomas induced in hamsters by BK virus, a human papovavirus. J. Natl. Cancer Inst., $61,875-883$.

Goldman, H. ANd Colle, E. (1976): Human pancreatic islets in culture: Effects of supplementing the medium with homologus and heterologus serum. Science, 192, 1014-1016.

Kawamura, A., JR. (1977): Preparation of labeled antibody. p. 45-52. In Fluorescent antibody techniques and their applications, 2nd ed., University of Tokyo Press, Tokyo.

King, D. L., Chick, W. L. And Kitchen, K. C. (1977): Pancreatic beta cell replication. p. 109114. In E. von Wasielewski and W. L. Chick [eds.]. Pancreatic beta cell culture, Workshop Conferences Hoechst, vol.5, Excerpta Medica, Amsterdam-Oxford.

Lambert, A. E., Blondel, B., Kanazawa, Y., Orci, L. And Renold, A. E. (1972): Monolayer cell culture of neonatal rat pancreas: Light microscopy and evidence for immunoreactive insulin synthesis and release. Endocrinology, 90, 239-248.

Morgan, C. R. And Lazarow, A. (1963): Immunoassay of Insulin: Two antibody system. Plasma 
insulin levels of normal, subdiabetic and diabetic rats. Diabetes, 12, 115-126.

OgAtA, Y. (1970): Morphologies and endocrine functions of rat pancreas in an organ culture system. Folia Endocrinol. Japan., 46, 148-162 (in Japanese).

Prince, G. A., Jenson, A. B., Billups, L. C. And Notkins, A. L. (1978): Infection of human pancreatic beta cell cultures with mumps virus. Nature, 271, 158-161.

Uchida, S., Watanabe, S., Aizawa, T., Kato, K., Furuno, A. and Muto, T. (1976): Induction of papillary ependymomas and insulinomas in the Syrian golden hamster by BK virus, a human papovavirus. Gann, 67, 857-865.

Uchida, S., Watanabe, S., Aizawa, T., Furuno, A. And Muto, T. (1979): Polyoncogenicity and insulinoma-inducing ability of BK virus, a human papovavirus, in Syrian golden hamsters. J. Natl. Cancer Inst., 63, 119-126.

Wicker, R. ANd Avrameas, S. (1979): Localization of virus antigens by enzyme-labeled antibodies. J. Gen. Virol., 4, 465-471.

Yoon, J. W., Onodera, T., Jenson, A. B. and Notkins, A. L. (1978): Virus-induced diabetes mellitus XI. Raplication of coxsackie B3 virus in human pancreatic beta cell cultures. Diabetes, 27, 778-781.

Fig. 1. A paraffin section of human embryo pancreas fixed with Bouin's solution and stained with IFA technique using anti-insulin guinea pig serum.

Fig. 2. Light microscopy of islet cells: Human embryo islet cells cultured for 3 days in Eagle's MEM supplemented with $10 \%$ calf serum. Clusters of islet cells have anchored to a glass coverslip and fanned out to make a monolayer formation.

Fig. 5. BKV infected human embryo beta cells. (a) BKV T-Ag (TRITC; $\longrightarrow$ ) was found in the nucleus of insulin (FITC; $\Longrightarrow$ ) containing beta cell. (b) BKV V-Ag (TRITC; $\longrightarrow$ ) was also found in the nucleus of beta cell (FITC; $\Longrightarrow$ ). 

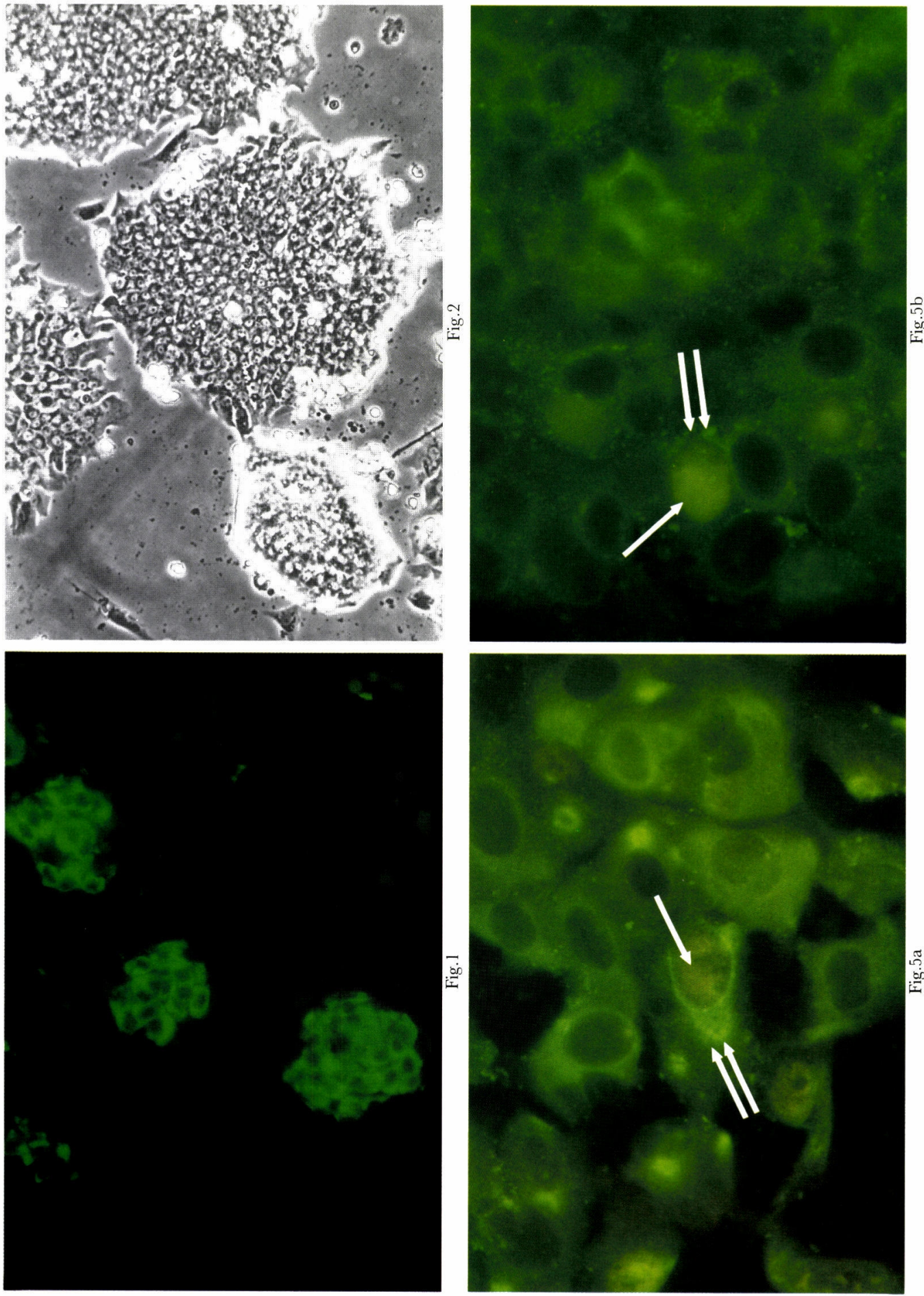